\title{
実構造物の調査結果に基づく 腐食鉄筋の力学性状の評価
}

\author{
大屋戸 理明 1 ・金久保 利之 2 -山本 泰彦 3 飯島 亨4 \\ 1正会員（財) 鉄道総合技術研究所 コンクリート構造（干185-8540 東京都国分寺市光町2-8-38） \\ E-mail: oyado@rtri.or.jp \\ 2正会員 筑波大学大学院助教授 システム情報工学研究科（†305-8573 茨城県つくば市天王台1-1-1） \\ E-mail: kanakubo@kz.tsukuba.ac.jp \\ 3正会員 筑波大学大学院教授 システム情報工学研究科（テ305-8573 茨城県つくば市天王台1-1-1） \\ E-mail: yamamoto@kz.tsukuba.ac.jp \\ 4正会員（財) 鉄道総合技術研究所 コンクリート材料（干185-8540 東京都国分寺市光町2-8-38） \\ E-mail: iijimat@rtri.or.jp
}

\begin{abstract}
腐食が進行した鉄筋は健全な鉄筋と異なる力学特性を示すことが多い。これは腐食による断面欠損が一 般に均一でなく, 特に断面積が最小になっている局所の変形挙動が全体の力学特性に影響を与えるためと 推測される. 本研究ではまず，構造物中の鉄筋のレプリカを作製して腐食状況を調べる技術を開発し，そ の有用性を確認した，次いで，環境条件が相違する実構造物や，長期暴露試験体等に配置されている鉄筋 の腐食状況について, 鉄筋のレプリカあるいは構造物等から切り出した鉄筋を試験片として, 3Dスキャナ により詳細に調査した。また，3Dスキャナのデータを元に，ノギスによって鉄筋の直径を計測した場合の 精度も併せて検証した. 最後に, 鉄筋の腐食による断面欠損の程度と分布状況が腐食鉄笳の力学性状に及 ぼす影響を考察した。
\end{abstract}

Key Words : corrosion, reduction of cross section, replica, caliper, stress-strain relationship

\section{1. はじめに}

長期間供用されている鉄筋コンクリート (RC) 構造物 が増加する中，それらの現有性能を適切に評価し，補修 や補強の要否を的確に判断することが求められている. 特に鉄筋の腐食による劣化が生じているRC構造物の性 能評価に際しては，鉄筋の腐食の程度を十分に把握し， その影響を適切に評価する必要がある.

鉄筋の腐食程度の指標としては，その断面積を用いる のが適切であると考えられるが，主にその効率的な計測 手法がないことなどの理由により，別の指標によって評 価されることが多い，既往の研究の多くは，質量減少率 $C$ (式(1)）を腐食の程度の指標として用い, 鉄筋の力学 性状を評価している ${ }^{1}$. 例えば，腐食した鉄筋の降伏強 度の評価には式(2)が用いられている。

$$
\begin{gathered}
C=\Delta w / w \\
f_{s y} / f_{s y n}=1-k \cdot C
\end{gathered}
$$

ここに, $C$ : 質量減少率, $\Delta w$ : 腐食に伴う減少質量, $w$ : 腐食前の質量, $f_{s x}$ : 腐食後の降伏強度, $f_{s y n}$ : 腐食前
の降伏強度, $k$ : 質量減少率 $C$ に比例した降伏強度の低 下の程度を表す係数である.

上記の質量減少率 $C$ は, 鉄筋全体の平均的な断面欠損 の程度を表すと解釈できるが，局部的に生じる腐食の状 態と直接的に関連する指標ではない. 一方，式(2)にお ける $k$ の実験值は研究毎に相違しており，1２程度の範 囲にある数值が提示されている. この $k$ の值の相違は, 腐食による鉄筋の断面欠損の程度とその軸方向の分布状 況が腐食鉄筋の力学特性に少なからず影響を与えている ことを示唆していると考えられる.

局部的な断面欠損の程度を知るためには，腐食鉄筋の 断面積を詳細に測定する必要がある，腐食した鉄筋の任 意断面における断面積を調べた研究としては, 電食によ り腐食させた試験体中の鉄筋について直径の軸方向の分 布を測定した例”があり，腐食の程度が大きくなるほど 腐食の不均一性を考慮する必要性があることを指摘して いる．また，筆者らは，自然暴露や電食によって鉄筋を 腐食させた RC はり部材から, それらの曲げ載荷試験後 に鉄筋を採取し，非接触レーザー方式3Dスキャナを用 いて断面積の軸方向分布を調査した ${ }^{3)}$. その結果, 試験 
体の腐食鉄筋の任意断面における断面減少率は, 平均断 面減少率の1２倍程度の範囲にばらついており，これが 力学性状に影響し得ることを示した.

しかし，実際の構造物の腐食条件は様々であり，既往 の成果をそのまま適用することはできない，また，実構 造物の鉄筋軸方向の腐食の分布を詳細に調査した例は極 めて少ない.

本文は，互いに異なる自然環境下に置かれている8つ の実構造物を対象とし，鉄筋腐食の事例が多い部位ある いはコンクリートのはく落や錆汁などが生じていた部位 の鉄筋の腐食状況を詳細に調查するとともに，腐食によ る鉄筋の断面欠損の程度（長さが $50 \mathrm{~cm}$ 程度以内の範囲 における任意断面の断面積）およびその軸方向の分布に 関する調査結果に基づき, 鉄筋の力学性状を適切に評価 する手法について検討した結果を論じたものである。ま た, 実構造物と試験体レベルとの性状の違いを確認する 目的で，3種類の自然暴露および電食試験体についても 併せて調査した.

腐食に伴う鉄筋断面積のばらつきの実態調査に際し, 最終的には実構造物の調査への適用を目標とするが，実 構造物の鉄筋腐食状況は雨かかりや日照などの部位毎の 条件によって相当異なると予想され，その差異を完全に 把握するのは現実的ではない．しかしながら，特に実構 造物の腐食事例の多い，かぶりの比較的小さい部位につ いては，コンクリートのはく落や錆汁などの外観および 打音などの調査により，範囲毎の腐食の有無などの大ま かなレベルは把握できると考えられる，本研究では，実 構造物のあらゆる場所の腐食のばらつきを対象とするの ではなく，事前の調査により選定した概ね一定の環境条 件および範囲（概ね $250 \mathrm{~cm}$ 四方以内）における腐食のばら
つきを検討対象とする.

なお，一般的な構造物調査の趣旨と実態を考慮すると， 鉄筋の腐食状況を調べる方法としては, 鉄筋を構造物中 に存置させたまま実施可能であることが望ましい，本研 究では, この範疇に属する調査方法として新たに開発し たレプリカを用いる手法の有効性を検証した後, この手 法を上述した実構造物の約 $1 / 3$ の調查に適用した。また， 従来から鉄筋の腐食状況を調べる方法として用いられる， ノギスにより鉄筋の直径を調査寸る手法 ${ }^{4}$ (ノギス法) に関し，その適用性についても検討を行った.

\section{2. 調査の概要}

\section{(1) 調査対象}

本研究では, 表-1に示した8種類の異なる実構造物部 位と3種類の試験体の計11を調査対象とした.これらの 構造物と試験体の外観の例を図-1に示寸.

実構造物は全て鉄道用として供されているもので，そ れぞれ1つずつの部位を調查対象とした. 調查対象部位 の内訳は, 柱が1, はりが1, 壁が3, スラブが3である. なお，以下の記述においては，簡便性を考慮して，調査 を行った実構造物部材と試験体を総称して「調査体」と 呼称し，腐食状況調査のために使用した鉄筋のレプリカ あるいは一部の調査に用いた実際の鉄筋そのものを「試 験片」と呼称することにする.

表-1中の調查体No.3 は文献) に示したスラブであり， 採取後引張試験を実施した鉄筋を試験片とした．調査体 No.10は文献)で示した実構造部材であり，その載荷試験 後に採取した引張鉄筋を試験片とした. かぶり，中性化

表-1 調査対象の一覧

\begin{tabular}{|c|c|c|c|c|c|}
\hline $\begin{array}{c}\text { 調査体 } \\
\text { No. }\end{array}$ & 構造物・部位 & 環境条件 & $\begin{array}{c}\text { かぶり・中性化深さ }(\mathrm{mm}) \\
\text { / 全塩化物イオン量 }\left(\mathrm{kg} / \mathrm{m}^{3}\right) / / \text { 腐食度* }\end{array}$ & $\begin{array}{l}\text { 推測される } \\
\text { 腐食要因 }\end{array}$ & 経年** \\
\hline 1 & 自然暴露試験体・はり7) & 初期塩分 & $20 \cdot 5 / 4.5 / \mathrm{III}$ & 塩害 & 10年 \\
\hline 2 & 促進劣化試験体・はりの & (電食) & $20 \cdot-/-/$ III & 電食 & ～1年 \\
\hline 3 & ラーメン高架橋・スラブ4) & 山間部 & $30 \cdot 24 / 1.4 / \mathrm{IV}$ & 複合 $(\text { 中性化 })^{+}$ & 30年 \\
\hline 4 & ラーメン高架橋・柱脚 & 沿岸部 & $40 \sim 50 \cdot 30 / 2.1 \diamond / \Pi b$ & 複合 (塩害) ${ }^{+}$ & 30年 \\
\hline 5 & 函きょ・側壁 & 汀線 & $35 \sim 45 \cdot 0 / 3 \sim 5 / \mathrm{IV}$ & 塩害 & - \\
\hline 6 & 自然暴露試験体・スラブ8) & 飛沫地带 & $20 \sim 50 \cdot 15 \sim 19 / 2.7 \sim 6.5 / \mathrm{III}$ & 塩害 & 10年 \\
\hline 7 & 函きょ・側壁 & 山間部 & $20 \sim 40 \cdot 40 / 1.6 \diamond / \mathrm{II}$ & 中性化 & 30年 \\
\hline 8 & ラーメン高架橋・スラブ & 都市部 & $13 \sim 78 \cdot 13 \sim 23 / 1.1 \sim 1.6 \diamond / \mathrm{II}$ & 複合 $(\text { 中性化 })^{+}$ & 30年 \\
\hline 9 & 函きょ・側壁 & 沿岸部 & $20 \sim 30 \cdot 5 / 0.35 / \mathrm{II}$ & 塩害 ${ }^{++}$ & 70年 \\
\hline 10 & ラーメン高架橋・はり5) & 都市部 & $50 \cdot 40 \sim 60 /-/$ III & 中性化 & 70年 \\
\hline 11 & スラブ & 飛沫地帯 & $20 \sim 50 \cdot 0 \sim 3 / 3 \sim 16 / \mathrm{IV}$ & 塩害 & 30年 \\
\hline
\end{tabular}

*腐食度 I : 部分的に軽微な腐食が認められる $\quad I a:$ 表面の大部分に腐食が認められる IIb : 部分的に断面欠損が認められる III : 鉄筋の全周にわたり断面欠損が認められる IV : 鉄筋断面が $1 / 6$ 以上欠損している

** 10 年単位に四捨五入 ${ }^{+}:$( )内は主体的と考えられる要因 ${ }^{++}$: 初期欠陥部位における飛来塩分による塩害 $-:$測定值無し ○中性化による塩分濃縮の影響を除くため, 深さ $100 \mathrm{~mm}$ 付近の深部の全塩化物イオン量を記載. 他は鉄筋近傍の測定值を記載. 
深さおよび塩化物イオン量の実測值等の情報により, 8 つの構造物の調查対象鉄筋の腐食要因を推測すると，中 性化によるものが4, 塩害によるものが4である.

一方，試験体は，はりが2，スラブが1の計3種類であ る.これらのうち調査体No.2のはりは，電食により強制 的に腐食させた試験体のであり, 塩害または中性化によ る鉄筋腐食との比較のために作製した. 残りの2種類は いずれも塩害により腐食させたものである.

調查体No.1 1 は，あらかじめ練混ぜ水にコンクリート $1 \mathrm{~m}^{3}$ あたり $10 \mathrm{~kg}$ の塩化ナトリウムを添加して試験体を作 製し，以後約12年間東京近郊で自然暴露（ただし暴露開 始当初約 1 年間は 1 日 2 回塩水を散布）した試験体であ る. 調査体No.6は, 沖縄の海岸に約10年間暴露した試験 体である8.

\section{(2) 鉄筋の腐食状況の調査方法}

本研究における鉄筋の腐食状況調查では，構造物から 切り出した鉄筋そのものを試験片とする方法に加え, 鉄 筋を構造物中に存置させたまま，そのレプリカを作製す る技術を開発し，この新技術によるレプリカを試験片と する方法も採用した.

腐食鉄筋のレプリカ作製の手順を図-2に示寸．まず， かぶり部と鉄筋周囲のコンクリートを除去して対象鉄筋 を露出させ，錆を除去する．次いで，この鉄筋を取り囲 むように 1 次型枠を設置する.この 1 次型枠の設置に要 する空間を確保するために, 鉄筋の周囲のコンクリート

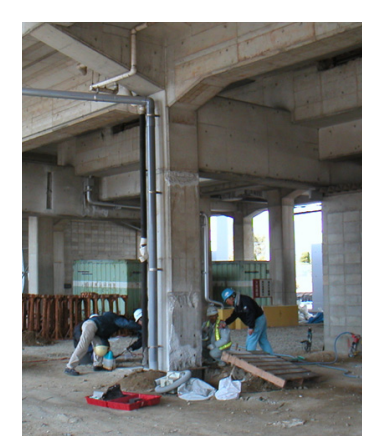

(a) 調査体No.4

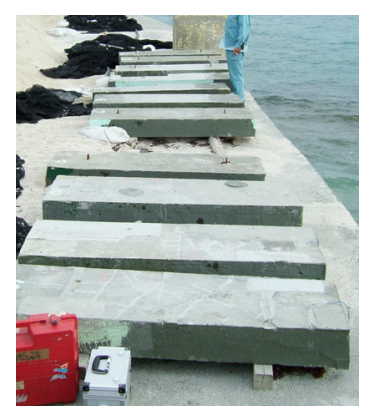

(c) 調査体No.6

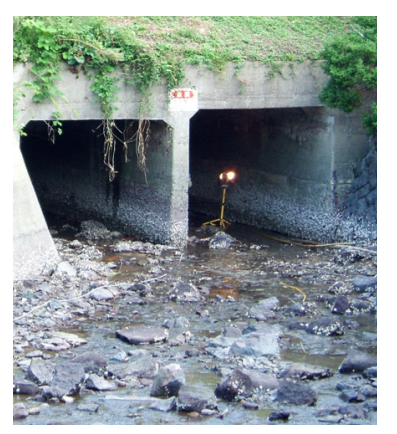

(b) 調査体No.5

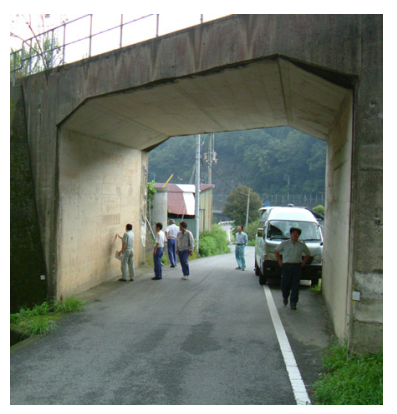

(d) 調查体No.7 図-1＼cjkstart構造物および試験体の外観の例
は背面を含めて $30 \mathrm{~mm}$ 程度除去しておく. その後, 1 次 型枠と対象鉄筋との間隙に液状シリコンゴムを注入し, 硬化後に切り開いて採取したシリコンゴムを 2 次型枠と する. 最後に 2 次型枠の内部に樹脂を注入し，この樹脂 の硬化体が対象鉄筋のレプリカとなる.

図-2の手順のうち，(a)および(b)の段階は現場での作業 となる. 2 次型枠の作製状況を図-3に示寸. この作業で は, 作業環境の条件により, シリコンゴムの硬化不良な どを生じる場合がある，現場作業では，天候や作業時間， 使用器具などを考慮して実施する必要がある.

調査体から採取した試験片の断面積の測定は, 文献” と同様，3Dスキャナを用いて行った。 最大スキャン長 さは，3Dスキャナの仕様により約400 mmとした. 調査 数量を表-2に示す. 表中において, 計測延長は全試験片 のスキャン長さの総和を意味し, 計測断面数はスキャン 断面の数を示す. スキャンデータ数は計206である.

3Dスキャナにより得られる鉄筋の表面形状の点群デ 一タから区分求積法により断面積を算出し，区分領域の 断面1次モーメントを算出して断面の図心を求めた.

スキャンデータは, 基本的に 1 つの試験片から1セッ トずつ測定しているが，3Dスキャナの最大計測長さ 400

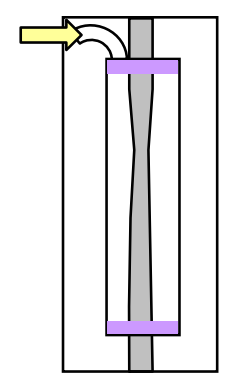

(a)
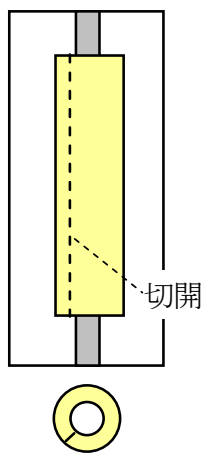

(b)

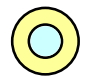

(c)

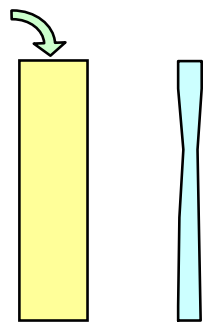

(d)
(a) 1 次型枠設置, 液状シリコンゴム注入
(b) シリコンゴム硬化後切開, 2 次型枠採取
(c) 2 次型枠内に樹脂を注入
(d) レプリカの完成

(a)(b) : 現場作業, (c)(d) : 室内作業

図-2 腐食鉄筋のレプリカ作製の手順

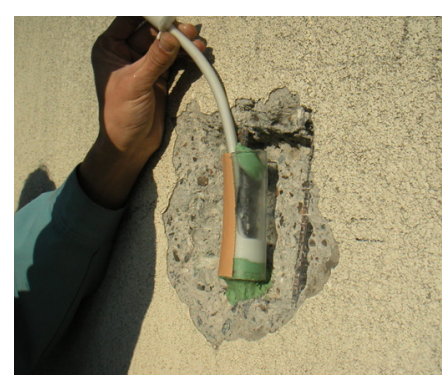

図-3 2 次型枠作製状況 
mmを超える長さの試験片の場合は，上下を反転して 2 回測定したため，1本の試験片から2セットのスキャン データを得ている。 また，計測ピッチに関しては，形 状が複雑でない調査体No.10の鉄筋の半数のみ $2 \mathrm{~mm} ヒ ゚ ッ$ チで測定したが，その他の場合は全て $1 \mathrm{~mm}$ ピッチで断面 形状を測定した.

錆の除去方法については，調査体から取り出した鉄筋 の場合はクエン酸二アンモニウム水溶液に浸漬した後に ワイヤブラシおよびピックを用いて除去した. 一方，レ プリカを作製する前の鉄筋のさびは，調査体No.5以外は 全て表面の凹凸が少なかったためサンドブラストにより 除去し，凹凸の著しい調査体No.5ではウォータージェッ トにより除去した.

\section{3. 腐食鉄筋の調査結果}

\section{(1) レプリカによる調査の適用性}

調査で得られたレプリカの外観の例を，採取した鉄筋 と比較して図-4に示す.レプリカは腐食鉄筋の欠損痕の

表-2 調査数量

\begin{tabular}{|c|c|c|c|c|}
\hline $\begin{array}{l}\text { 調査 } \\
\text { 体No. }\end{array}$ & $\begin{array}{l}\text { スキャンデ } \\
\text { ータ数* }\end{array}$ & $\begin{array}{c}\text { 計測延長 } \\
\text { (mm) }\end{array}$ & $\begin{array}{l}\text { 計測 } \\
\text { 断面数 }\end{array}$ & 試験片** \\
\hline 1 & 35 & 6893 & 6808 & $\mathrm{D} 13 \triangle$ \\
\hline 2 & 4 & 882 & 873 & $\mathrm{D} 13 \triangle$ \\
\hline 3 & 15 & 2182 & 2167 & $D 13,16 \triangle$ \\
\hline 4 & 4 & 560 & 556 & $\mathrm{D} 10 \triangle$ \\
\hline 5 & $18(6)$ & 4537 & 4491 & $\phi 9,19>$ \\
\hline 6 & $45(39)$ & 5211 & 5089 & $\mathrm{D} 13 \diamond$ \\
\hline 7 & $9(9)$ & 2210 & 2188 & D25,D19 $\nabla$ \\
\hline 8 & 9(9) & 1161 & 1138 & $D 13,16 \nabla$ \\
\hline 9 & $12(12)$ & 4235 & 4212 & $\phi 22 \nabla$ \\
\hline 10 & 36 & 10051 & 6228 & $\phi 22 \triangle$ \\
\hline 11 & 19 & 4101 & 4075 & $\mathrm{D} 10,13 \triangle$ \\
\hline 合計 & $206(75)$ & 42023 & 37825 & \\
\hline \multicolumn{5}{|c|}{ 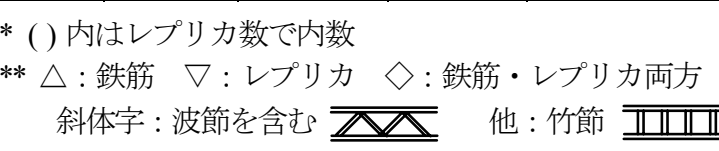 } \\
\hline
\end{tabular}

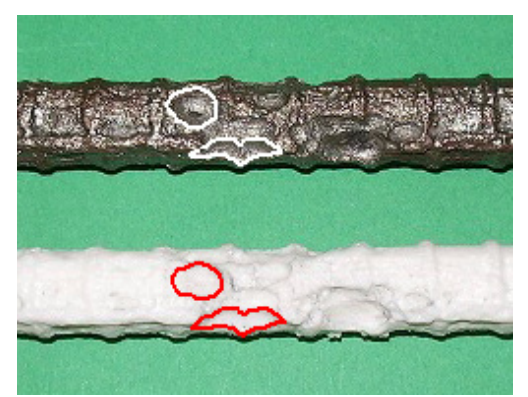

注 : 同じ欠損痕の一部にマーキングを付している 図-4 レプリカと鉄筋の外観の比較（調查体No.1）
凹凸を良好に再現している．レプリカと鉄筋の断面積分 布を比較して図-5に示す. 図では1次型枠または2次型枠 の再現精度により，レプリカは鉄筋よりも約 $1 \mathrm{~mm}^{2}$ 程度 小さいが，その差は断面減少量の検討範囲 (4. 以降参 照）に対して十分小さい. 断面積の軸方向分布はほぼ一 致していると見なせることから，レプリカによる断面積 の軸方向分布の把握が可能であることが分かる.

\section{(2) 採取鉄筋の外観}

調査で得た鉄筋の外観の例を図-6に示す．なお，写真 では，鉄筋を採取した後に時間が経過して撮影した試験 片の表面が発錆しているが，形状は概ね錆落とし直後の 状態を保っている.

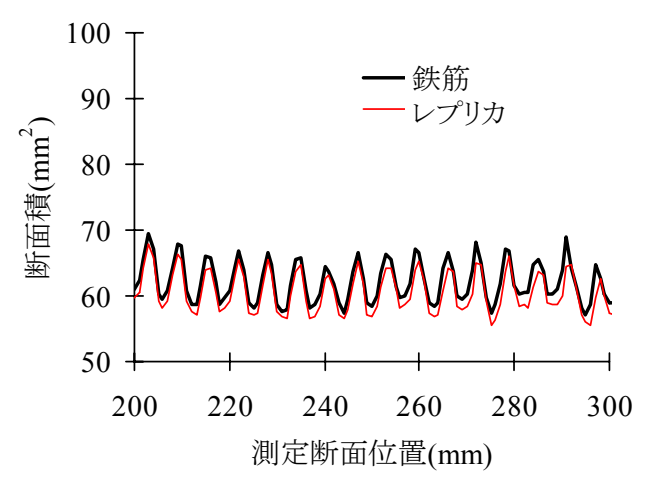

図-5 レプリカと鉄筋の断面積軸方向分布の比較

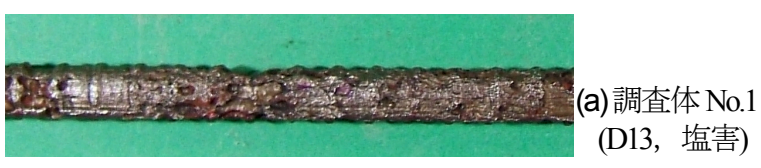

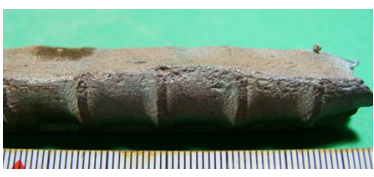

(b) 調査体No.3 (D16, 中性化)

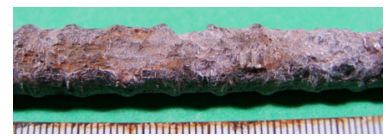

(c) 調査体No.2(D13，電食)

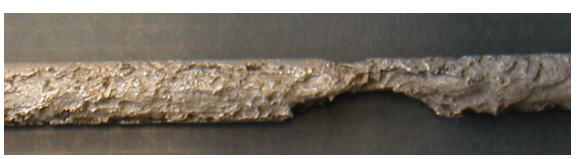

(d) 調查体 No.5 ( $\phi 19$, 塩害)

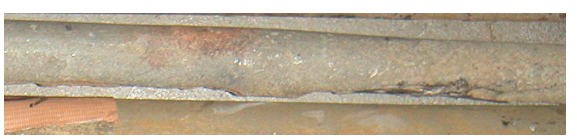

(e) 調査体 No.10 ( $\phi 22$, 中性化)

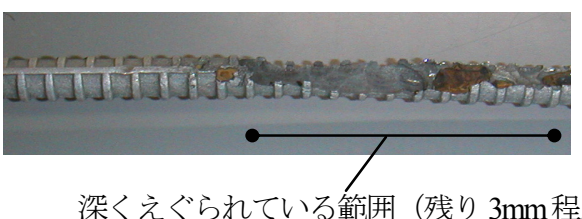

(f) 調査体 No.11 (D10, 塩害)
深くえぐられている範囲 (残り $3 \mathrm{~mm}$ 程度の厚み)

図-6 調査で得た鉄筋の外観の例 
塩害による腐食を生じた調査体No.11の鉄筋は，ほぼ 健全な場所がある一方で，特定の場所に偏って深くえぐ られるように腐食しており，陽極部と陰極部が明確に分 離する典型的なマクロセル腐食の様相を呈している。一 方，同じく塩害の調査体No.1の鉄筋は，細部では腐食箇 所と比較的健全な箇所が区分できるものの，調查体 No.11よりも広範囲にわたり腐食している，また，同じ く塩害の調查体No.5では，腐食部分が表面全体に分散し ている一方，著しく腐食している箇所も存在している. この著しい腐食はコンクリートの打継目に位置しており， 明かにコンクリート内部に海水が浸入した形跡が確認さ れている.
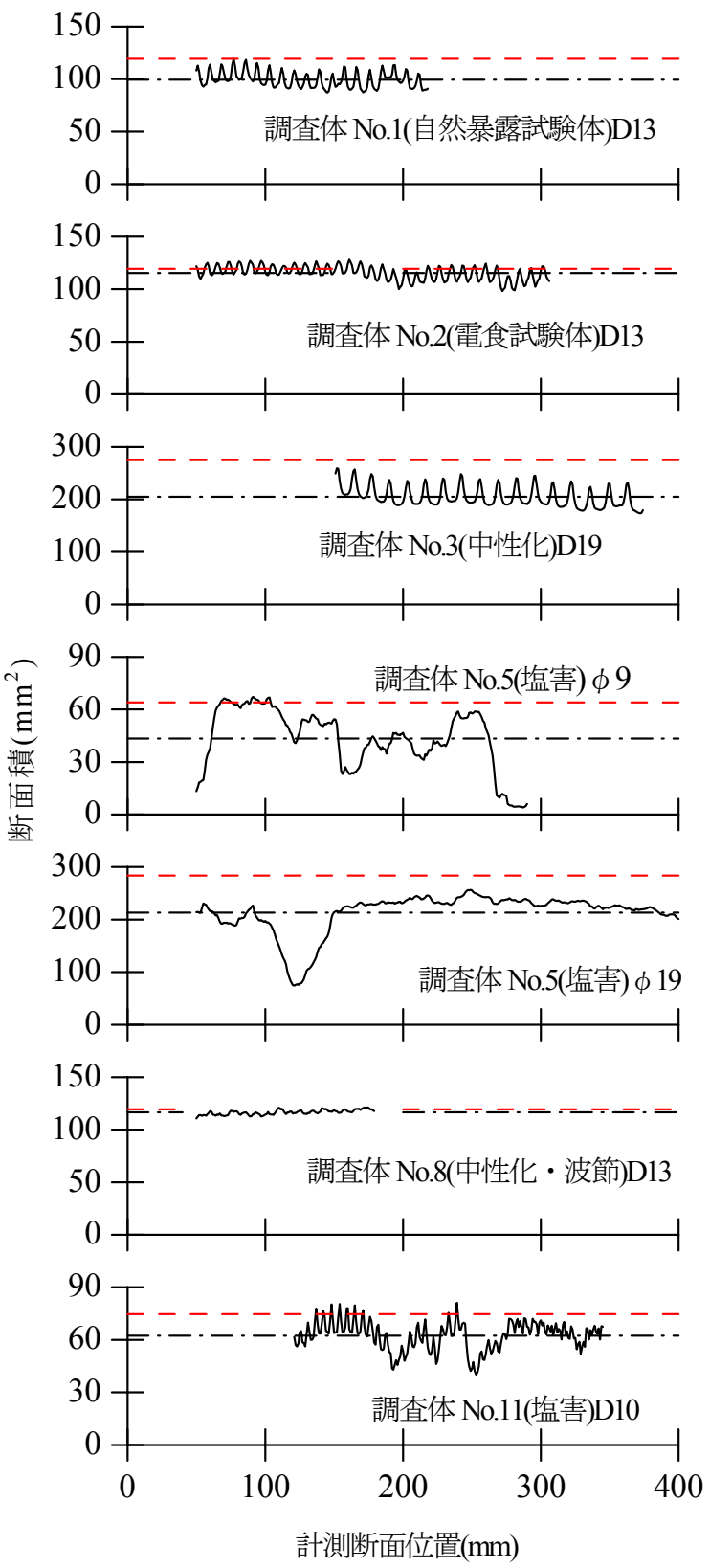

(破線 : 公称断面積 一点鎖線 : 平均断面積)

図-7 鉄筋断面積の軸方向分布の例
中性化による腐食を生じた調査体No.3の鉄筋は，片面 だけが著しく削られるように腐食しており，腐食量は異 なるが丸鋼である調査体No.10の鉄筋も同様である．電 食により腐食した調查体No.2の鉄筋は，表面全体が腐食 している.

\section{(3) 鉄筋断面積の軸方向分布}

3D スキャナにより形状を計測し，算出した鉄筋断面 積の軸方向分布の例を図-7に，頻度分布の例（縦軸は計 測断面数で基準化）を図-8に示す.

図-7によると，塩害の鉄筋No.1は，節の痕跡を明確に 保ちながら, 場所により断面積の相違が見られる. 電食 による腐食を生じた調査体No.2では，塩害のNo.1と比べ， 節の山と谷の差がやや小さく，節の部分が他よりも先に 腐食し始めているように観察される，中性化による腐食 を生じた調査体No.3では，図-6(b)のように片側のみ腐食 しているが，断面積の軸方向分布により節の痕跡が十分 確認できる．塩害で腐食を生じた調査体No.5の鉄筋（ 9）は，断面積の軸方向分布が極端に変動しており，頻 度分布からもそれが確認できる．塩害の調查体No.11の 鉄筋も，外観（図-6(f)）からも観察されるように，著し く腐食している箇所とほぼ健全とみなせる箇所が明確に 分離している. 同じ調査体No.5鉄筋（ $\phi 19 ）$ では，比較 的太い鉄筋でありながら局部的に著しく欠損を生じた例 である（図-6(d)参照）。図-7によると，塩害により腐 食した実構造物の調査体No.5,11の鉄筋は，同じく塩害の 自然暴露試験体から採取した調査体No.1の鉄筋と比べて, 最大断面積と最小断面積の差が顕著である.
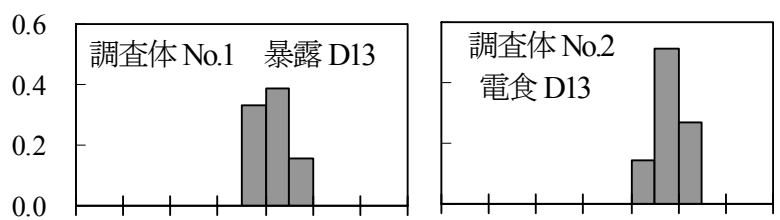

$\begin{array}{lllllll}0 & 24 & 48 & 72 & 96 & 120 & 144\end{array}$
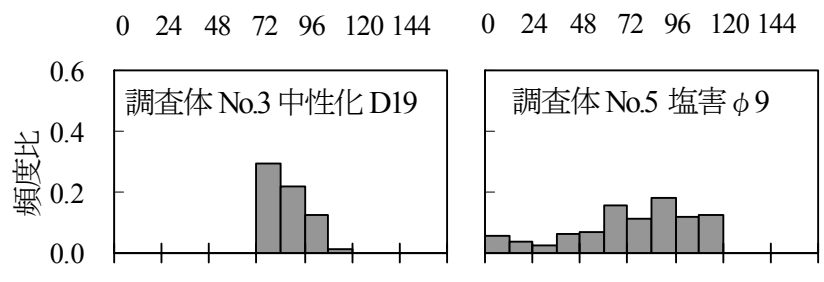

$0 \quad 56 \quad 112168224280336$

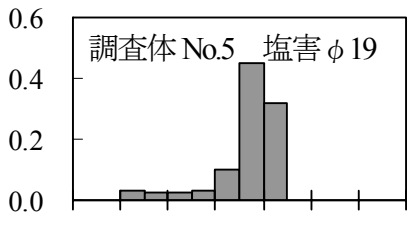

$\begin{array}{lllllll}0 & 14 & 28 & 42 & 56 & 70 & 84\end{array}$

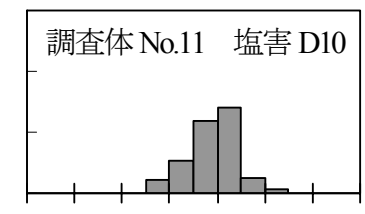

$0 \quad 58 \quad 116174232290348$

$\begin{array}{lllllll}0 & 16 & 32 & 48 & 64 & 80 & 96\end{array}$

図-8 鉄筋断面積の頻度分布の例 


\section{4. 断面積頻度分布の評価}

\section{(1) 特性值算出法の概要}

腐食鉄筋の断面積のばらつきを考察するにあたり，特 性值の算出法を検討寸る.

測定した鉄筋は，引張試験を実施した後の試験片が含 まれている．これらの鉄筋は破断部分で絞りが生じ，断 面積が縮小しているので, 破断面から概ね1節の部分を 集計範囲から除外した.

また，3Dスキャナに鉄筋を傾けて設置した場合は， 計測断面が楕円となり，測定断面積に影響することが㲘 念される ${ }^{3)}$. 通常の試験片で傾きが過大な場合は，レー ザー光が鉄筋から外れて測定できなくなるため, 測定デ 一タが自動的に棄却される。しかし，試験片が曲がって いる場合は，測定できた場合でも部分的に著しい傾きを 生じている可能性があり, また，鉄筋自体の変形のため に断面積が変動している可能性もある. 従って, 今回の 検討では，断面図心の軸方向のずれを参考とし，明らか に曲がりが確認される部分を集計範囲から除外した。

次に，劣化の指標となる特性值の算出方法を説明する. 断面積の減少分と元の断面積の比は, 質量減少率に 相当する指標となる. 本研究では, 個々の試験片の平均 的な腐食の程度を示寸平均断面減少率 $R_{\text {ane }}$ (式(3)），断 面毎の局所断面減少率 $R_{\text {local }}$ (式(4)）ならびに個々の試験 片における最大断面減少率 $R_{\text {max }}$ (式(5)）を算出した.

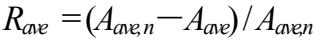

$$
\begin{aligned}
& R_{\text {local }}=\left(A_{\text {ove },}-A_{\text {local }}\right) / A_{\text {are }, n} \\
& R_{\text {max }}=\left(A_{\text {are }, n}-A_{\text {min }}\right) / A_{\text {are, }}
\end{aligned}
$$

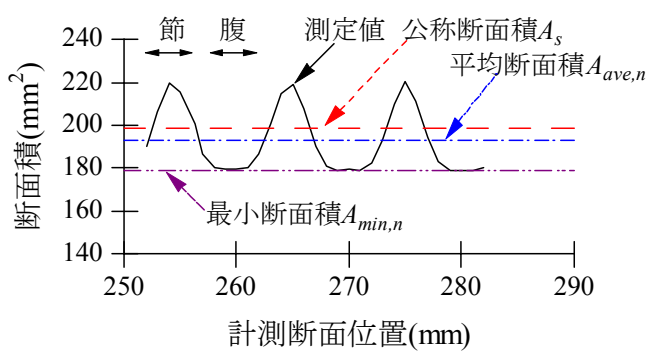

図-9 健全な鉄筋(D16)の断面積と平均断面積の例

表-3 健全な鉄筋 $(\mathrm{D} 10,13,16)$ の公称・平均・最小断面積 (別途入手した鉄筋の測定値)

\begin{tabular}{ll|c|c|c|c}
\hline & D10 & D13 & D16 & 平均 \\
\hline 公称断面積 $A_{s}$ & $*$ & 71.3 & 126.7 & 198.6 & - \\
\hline 平均断面積 $A_{a x, n}$ & $*$ & 68.9 & 119.4 & 192.7 & - \\
\hline 最小断面積 $A_{m i n}, n$ & $*$ & 64.7 & 113.7 & 178.1 & - \\
\hline$A_{a x e, n} / A_{s}$ & 0.966 & 0.942 & 0.970 & 0.960 \\
\hline \multicolumn{5}{|c}{} & $*$ 単位 $\left(\mathrm{mm}^{2}\right)$
\end{tabular}

ここに, $A_{\text {ar, } n}$ : 腐食前の各試験片の平均断面積, $A_{\text {are }}$ : 腐食後の各試験片の平均断面積, $A_{\text {loal }}$ : 腐食鉄筋の 着目断面における局所断面積, $A_{m i n}: 1$ 本の試験片の最 小断面積である. 各試験片において $R_{\text {bocl }}$ の最大值が $R_{\text {max }}$ となる.

一方，腐食量に関する指標として，個々の試験片にお ける平均断面減少量 $D_{a r}$ (式(6)），断面毎の局所断面減 少量 $D_{\text {looal }}$ (式(7)) ならびに個々の試験片における最大断 面減少量 $D_{\text {max }}$ (式(8)）を算出した.

$$
\begin{aligned}
& D_{\text {ave }}=A_{\text {are }, n}-A_{\text {ave }} \\
& D_{\text {local }}=A_{\text {are }, n}-A_{\text {local }} \\
& D_{\text {max }}=A_{\text {are }, n}-A_{\text {min }}
\end{aligned}
$$

これらの算出式では，腐食鉄筋の断面積はもとより， 健全鉄筋の断面積 $A_{\text {are }} n$ の值が重要になる. 健全鉄筋の平 均断面積 $A_{\text {amen }}$ は, 本来, 同じ調査体から採取した腐食し ていない鉄筋のデータを用いるのが適当である.しかし， 実構造物の調查では，健全な場所の局部破壊検查が実施 できなかったこと，試験体では試験開始時に当該検討項 目を想定していなかったことにより，健全な鉄筋を採取 できなかった．このため，健全鉄筋の平均断面積 $A_{\text {ar, }}$ は, 丸鋼の場合は公称断面積と同一とし，異形鉄筋の場合は 同じ種類の健全な鉄筋の断面積計測結果（例を図-9およ び表-3に示す）により，表-3の $A_{\text {ar, }} / A_{s}$ の平均值0.96を用 いて, 公称断面積 $A_{s}$ （健全鉄筋の值，以下同じ）を0.96 倍に低減した想定值を用いた。 表中の $A_{\text {ax, } n}$ についな, 実際には製造会社等により異なるが，当該值は1を下回 り（即ち $A_{\text {ar }}$, 以 は公称断面積を下回る），その程度は若干 であると考えられるので，表-3の值は概ね正しいと見な せる。 なお，一部の実構造物（調査体No.5，10，11）の 試験片では, 式(3)で算出した平均断面減少率 $R_{a n e}$ が負と なり, 腐食により断面積が増加するという適切でない結 果となった. これらの鉄筋の腐食前の平均断面積 $A_{\text {are } n}$ の 真值は，製造時のばらつき等のために上記想定值より大 きいにもかかわらず，式(3)に真值より小さい上記想定 值を用いたため， $R_{\text {ane }}$ 負になったと考えられる. そこ でこれらについては, 採取した各試験片の平均断面積の うち当該調查体中最大の值を $A_{a n e n}$ として採用した.

\section{(2) 鉄筋径の影響}

本研究で検討対象とする試験片は, 直径 (公称径) が $9 \mathrm{~mm}$ から $25 \mathrm{~mm}$ 程度まで様々であり，これによって特性 值が影響を受けることも䀣念される. そこで, 調査で得

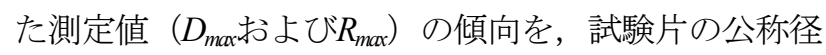
別に分類して調查した. 結果を示した図-10のうち, 最 大断面減少量 $D_{\text {mar }}$ にいては, 公称径が大きくなるほど, より断面減少量の大きいデータが観察されているが，こ 
れは元の鉄筋が太い場合に腐食量の上限が大きくなるこ とから自明である。また， $D_{\text {max }}$ が $80 \mathrm{~mm}^{2}$ 以下のデータに ついては, 公称径と関係なく点が存在する。 これは, 腐 食の絶対量は当然ながら供用年数や腐食環境によって決 まるためである，これより，断面減少量が $80 \mathrm{~mm}^{2}$ を超え る腐食の著しい範囲を検討寸る場合は，対象試験片の公 称径が $16 \mathrm{~mm}$ 以上になることに留意する必要があるもの の，このことを除けば，断面減少量を検討する場合に公 称径の影響を考慮する必要はないことが分かる.

一方, 最大断面減少率 $R_{\text {max }}$ についは, 公称径が小さ くなるに従って断面減少率のより大きいデータが現れて いる. 特に公称径が $10 \mathrm{~mm}$ 以下の鉄筋については， $R_{\text {max }}$ が 0.5を超えるような極端に断面減少率の大きいものがあ る.これは，断面積が元々小さい細い鉄筋は断面減少率 算出時の分母が小さくなり，このことで結果的に大きい $R_{\text {max }}$ が算出されることによると考えられる.

なお，図中×で示した点は，他と著しく異なる值を示 している.この点は図-6(d)で示した，打継目から直接 海水が進入し，その部分だけ著しく腐食した鉄筋である. 本研究は概ね一定の環境条件における腐食のばらつきを 主な対象としているので, 以降これを区別して表記する.

\section{(3) 断面減少量の標準偏差}

各試験片の局所断面積 $A_{\text {local }}$ の標準偏差 $\sigma_{D}$ (局所断面減 少量 $D_{\text {local }}$ の標準偏差と同值) と平均断面減少量 $D_{\text {are }}$ との 関係を調べ，腐食鉄筋の断面積の頻度分布を精査した。

結果を図-11(a)に示寸． $D_{a x}$ と的との間に明確な相関は 確認できない，また，今回集計したデータでは，この他
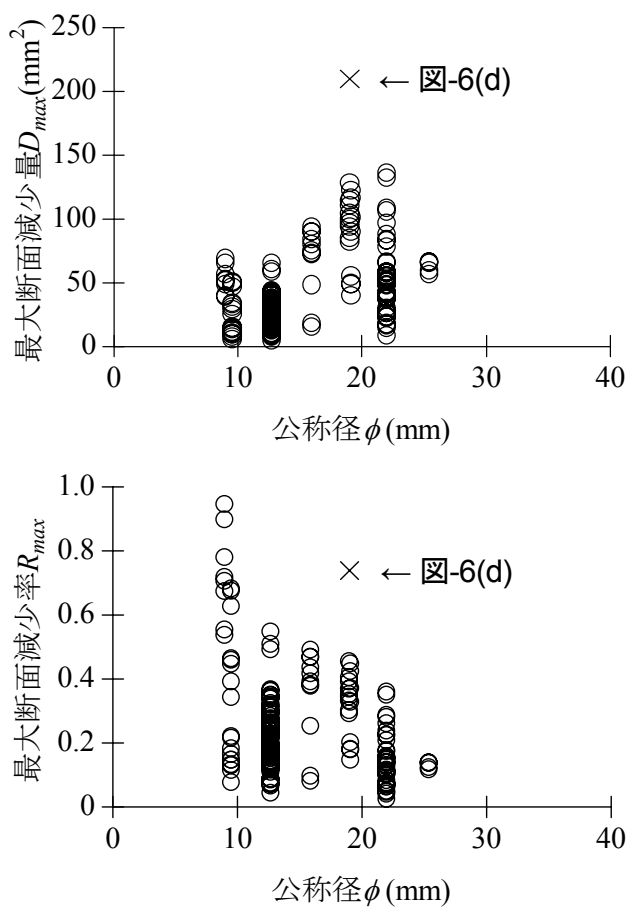

図-10 公称径と最大断面減少量 - 率の関係
に后を決定づける要因も見出せなかった.

ここで， $0 \leqq D_{a x e} \leqq 30$ こおいて $\sigma_{D} \fallingdotseq 7 \sim 9$ の範囲に点群が 集中して存在する（1 点鎖線枠内）。これらは何れも, 自然暴露試験体（調查体No.1と6）から採取した試験片 であった。調査体No.1,6のみのデータを抽出して図-11(b) に示す。これらの自然暴露試験体から採取した試験片は, 腐食の程度にかかわわらず，局部的な断面減少量のばらつ きが一定の範囲に収まる結果となった。この2種類の試 験体は，製作時期は近いものの，使用材料，配合，製作 者および暴露環境とも全く異なる.このように，全く別 の試験体の腐食のばらつきがほぼ同じ傾向を示したこと から, 断面減少量の標準偏差は, 平均断面減少量の大小 とそれほど相関はないことが分かる。 なお，自然暴露試 験体と実構造物でばらつきに差異を生じた理由は不明で あるが，自然暴露試験体は実構造物に比べ部材が小さい ため, 結果として比較的均質に製作されたことが理由の

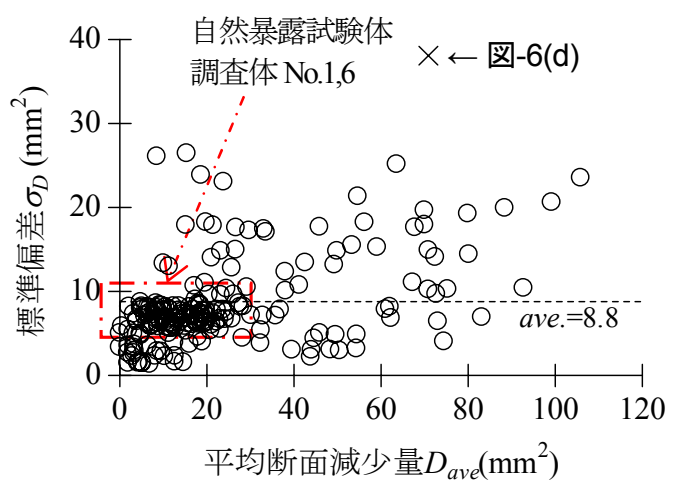

(a) 全データ

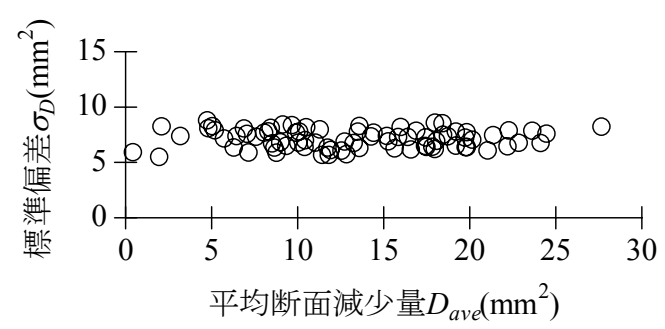

(b) 調查体No.1,6の夕抽出

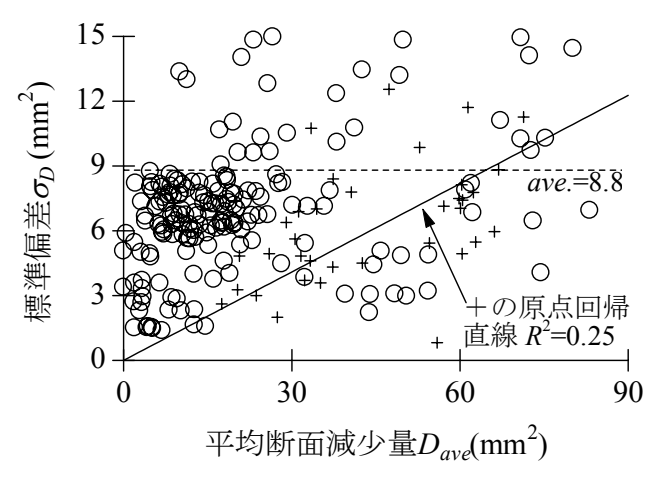

(c) 文献) を追記(十印)

図-11 平均断面減少量と断面積の標淮偏差の関係 
一つとして考えられる. 図-11(a)の 1 点鎖線枠は, 全試 験片の平均 $8.8 \mathrm{~mm}^{2}$ （破線）に近接しており，試験体と実 構造物の傾向は一致している.

ところで文献》 では，平均断面減少率が大きいほど断 面減少率の標準偏差が大きい傾向があると述べられてい る.一般には，腐食が進行するほど健全な場所との差異 が大きくなると解釈するのが自然であり, 文献9 の考察 もこれと一致する. 文献” で示された結果を断面減少量 に換算し，図-11(a)に追記して図-11(c)に示寸。なお図11(c)は, 文献9) のデータと比較しやすくするため, 図11(a)の一部の範囲を拡大している. これによると, 文 献9)のデータは本調査結果のデータ範囲に包含されてい ることがわかる．また，文献9)のデータは100 mm毎に質 量を測定して検討しており，断面積の測定結果ではない こと, $R^{2}$ が 0.25 と十分小さいことから，断面積の標準偏 差は平均断面減少量と相関が弱いことが分かる．また本 調査では，標準偏差についての他の影響因子も見出せな かった. そこで本研究では, 標準偏差は断面減少量の大 小に関係なく一定と仮定して検討を進める.この仮定は, 先の一般的解釈と異なり, ある場所で腐食が進行しても 他の場所でも腐食が開始するので，ばらつきは結果的に ある範囲に収まるという考え方になる。これは冒頭に述 べたように，本研究は構造物のあらゆる場所の腐食のば らつきを取り扱うのではなく, 比較的均一な腐食環境に ある特定の部位を対象としていることにもよる.

以下, 標準偏差 $\sigma_{D}$ の一定值として, 試験体No.1,6の值 にも近い，全試験片の $\sigma_{D}$ の平均值 $8.8 \mathrm{~mm}^{2}$ を採用する. $\sigma_{D}$ は(4)で後述するように平均断面減少量 $D_{a x}$ を用いて最大 断面減少量 $D_{\text {max }}$ を予測するためのパラメータとして使用 するが，異なる標本の標準偏差の平均值であることから 数学的な意味はない. 当然ながらこれを上回る標準偏差 をとる可能性はあり，これは図-11(a)より自明である。 標準偏差の影響因子については, 今後の課題である.

以上により，平均断面減少量が大きくなること自体で 局所断面減少量自体のばらつきはあまり影響を受けない と推測されたので, 標準偏差は断面減少量の大小に関係 なく一定值であると仮定し, 最大断面減少量 $D_{m a x}$ と平均 断面減少量 $D_{a v e}$ の関係について検討を進める.

\section{(4) 断面減少量}

前述の考察に基づき, 局所断面減少量の最大值 $D_{\text {max }}$ を, 平均断面減少量 $D_{a x}$ を用いて表現する方法を検討する. $D_{a x e}$ と $D_{\text {max }}$ の関係を図-12(a)に示す。これより，点群は直 線 $D_{m a x}=D_{a x e}$ を下限とし, これを縦軸の正の方向に一定量 だけシフトした範囲に存在していることがわかる.

ここで断面減少量 $D_{\text {loal }}$ が，平均值 $D_{\text {are }}$ ・標準偏差 $\sigma_{D}$ の 正規分布に従うと仮定する. 最大断面減少量 $D_{\text {max }}$ は $D_{\text {local }}$ の各試験片における最大值であるので, 各試験片の $D_{\text {lood }}$
が概ね $D_{a v e} \pm 3 \sigma_{D}$ の範囲にあるとすれば，最大断面減少量 $D_{\text {max }}$ は $D_{a x}+3 \sigma_{D}$ と予測できる.この場合の非超過確率は 99.9\%となる.これは当該鉄筋に対する予測であるが, 他の鉄筋を含む全体に対しては，(3)に述べたとおり標 準偏差 $\sigma_{D}$ は平均断面減少量 $D_{\text {ane }}$ にかかわ和らず一定とみな し，この值として $\sigma_{D}=8.8 \mathrm{~mm}^{2}$ を用いれば，最大值の予測 值は図-12(a)に併記した実線で表せる。

ここで, 図-12(a)に示した実線は点群の上限值でなく 期待值を示すことに注意を要する．通常，正規分布に従 う標本に対し, 平均值に標準偏差の3倍を加えた值は, 当該標本における観測值の上限付近の值をとる. 即ち, 個々の鉄筋の最大断面減少量は, 当該鉄筋の平均断面減 少量に標準偏差の3倍を加えた值で予測できる. 一方, 図-12(a)では互いに異なる鉄筋（標本）の平均值と最大 值の関係に着目している. 図-12(a)の実線は，全ての鉄 筋の標準偏差の代表值として平均值 $\sigma_{D}=8.8 \mathrm{~mm}^{2}$ を用い

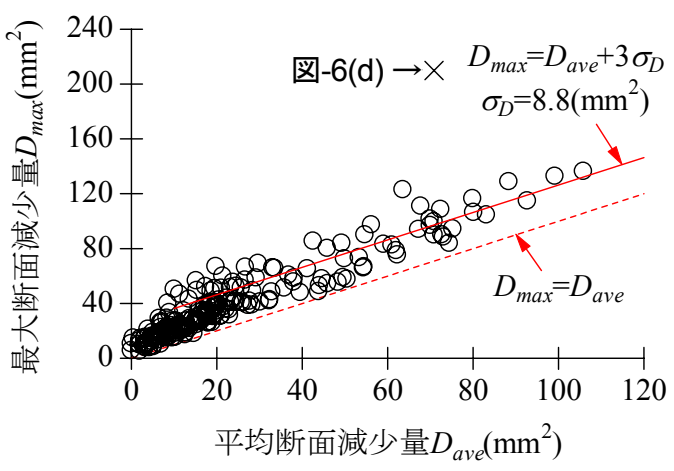

(a) 全データ

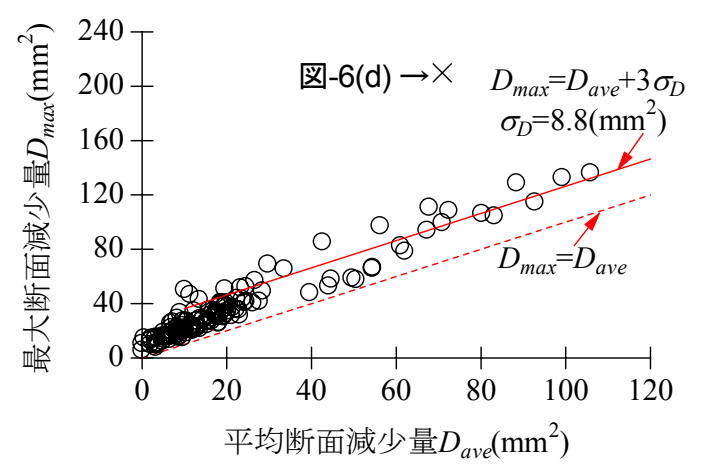

(b) 塩害データ

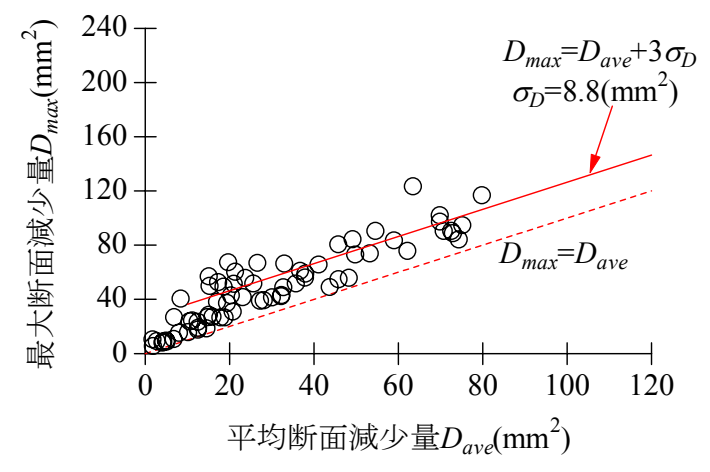

(c) 中性化データ

図-12 $D_{a x e}$ と $D_{\max }$ の関係 
ており， $D_{\max }$ の最大值でなく期待值を示す．前述のよう に $\sigma_{D}$ 自体は数学的に有意でないものの，図-12(a)の実線 は点群の（上限でなく）中心にあることから，最大值を 予測するためのパラメータとして $\sigma_{D}=8.8 \mathrm{~mm}^{2}$ を仮定した ことの妥当性が伺える，また，図-12(a)によると， $D_{a v e}$ が増加しても点群の存在範囲が広がらずに一定の幅に収 まっており，(3)で述べた標準偏差を一定とする仮定が 概ね妥当であることが窥える。

なお，図-12(a)中で，平均断面減少量が0のときの最 大断面減少量 $D_{\max }$ は, 健全鉄筋における平均断面積と腹 の断面積の差を示し有意でないので，点群の存在範囲を 参考とし， $D_{a n e}<10 \mathrm{~mm}^{2}$ の範囲には実線を描画していない また，図-6(d)に示した打継目から海水の影響を受けた 試験片（×点）については，他と比べて著しく離れた位 置にある. 最大断面減少量は平均断面減少量のおよそ3 倍である $\left(D_{a v e} \fallingdotseq 70 \mathrm{~mm}^{2}\right.$ に対して $\left.D_{m a x} \fallingdotseq 210 \mathrm{~mm}^{2}\right)$. これは 図-6(d)に示したとおり特異な試験片であるが，このよ うな極端に一様でない腐食条件下では上述の予測は当て はまらないことに注意する必要がある.

腐食要因（塩害および中性化）による $D_{a v e}-D_{\text {max }}$ 関係 の相違を検討するため, 図-12(a)を腐食要因毎に区分し て図-12(b)，(c)に示す．腐食要因による違いは明確には 観察されず，塩害は中性化よりも局部的に大きい欠損を 生じると考察した文献)の考察と相違する. これは文献 の調査数量の少なさなどによると考えられる. 一般に, 塩害により腐食した鉄筋は中性化によるものよりも孔食 が顕著で，局部的な断面欠損も大きいと考えがちである が，本研究の測定条件下で平均断面減少量と最大断面減 少量だけに着目する限り, そのような傾向は小さい.

\section{(5) 断面減少率}

従来，腐食が鉄筋および部材の力学性能へ与える影響 を考察する場合では，減少量を元の值で除した「率」

（質量減少率や断面減少率）が指標として主に用いられ てきた.これらの指標は，強度等の特性值の元の值に対 する低減率（強度減少率等）と直接比較しやすく，考察 に便利である.しかし，同じだけ腐食しても細い鉄筋で は太い鉄筋に比べて断面減少「率」が著しく大きくなる など，腐食のばらつきを議論する場合に不都合を生じる。 即ち, 腐食の進行を直接表す指標は断面減少「量」であ り，「率」は元の值に大きく影響されることに注意が必 要である. 本研究ではこの点を踏まえ, 既往の研究の経 緯と利便性に鑑み, 断面減少率に関する考察を試みる.

各試験片の平均断面減少率 $R_{a v e}$ と最大断面減少率 $R_{\text {max }}$ の 関係を図-13に示す.ここで， $\triangle$ 点は公称径が $10 \mathrm{~mm}$ 以下 の鉄筋を示しているが，これらは公称径 $10 \mathrm{~mm}$ を上回る 鉄筋を示す○点群からの離融が大きい. これは前述のよ うに， \点は鉄筋が元々細いために，わずかな断面積の
差が大きく表現されるためである.

(4)の考察において, 最大断面減少量は平均断面減少 量から推定できることが確認できたので，これを力学的 な考察に用いるため, 腐食のばらつきを「量」で見積も ったうえで「率」の評価への展開を試みる.

図-11 12により, 最大断面減少量 $D_{\max }$ を平均断面減 少量 $D_{\text {ane }}$ を用いて式(9)のように表す． $R_{\text {max }}$ は $D_{\text {max }}$ を元断面 積で除し，式(10)で表せる.

$$
\begin{gathered}
D_{\text {max }}=D_{\text {ave }}+26.4\left(\mathrm{~mm}^{2}\right) \\
R_{\text {max }}=D_{\text {max }} / A_{\text {ave }, n}=D_{\text {ave }} / A_{\text {ave }, ~}+26.4 / A_{\text {ave } n} \\
=R_{\text {ave }}+26.4 / A_{\text {ave }, ~}
\end{gathered}
$$

本研究の検討範囲の最大・最小径であるD25とD10に 対して式(10)の関係を図示すると図-14のようになる。即 ち， $R_{\text {max }}$ は $R_{\text {ave }}$ と元の断面積 $A_{\text {aven }}$ に依存し, 図示した $y$ 切片 はD25（26.4/ $A_{\text {aven }}=0.0543 ）$ とD10 $\left(26.4 / A_{\text {aren }}=0.383 ）\right.$ で大き く異なる.このように鉄筋径の広い範囲を対象として $R_{\text {max }}$ を $R_{\text {ane }}$ により表現することは適切でないと考えられる が，既往の研究との比較のため，基準となる $R_{\max }-R_{\text {ave }}$ 関 係を検討する. 過去の検討例の多い細径の鉄筋に対して 検討するため, D10に対し $R_{a v e}=0.5$ 上限として点群の範 囲の中心 (対角線) を図示すると図-14の一点鎖線のよ うになり，最大断面減少率は平均断面減少率の概ね $21 ２$ 倍であるとする既往の知見 ${ }^{3)}$ と概ね一致する結論が得ら れる。

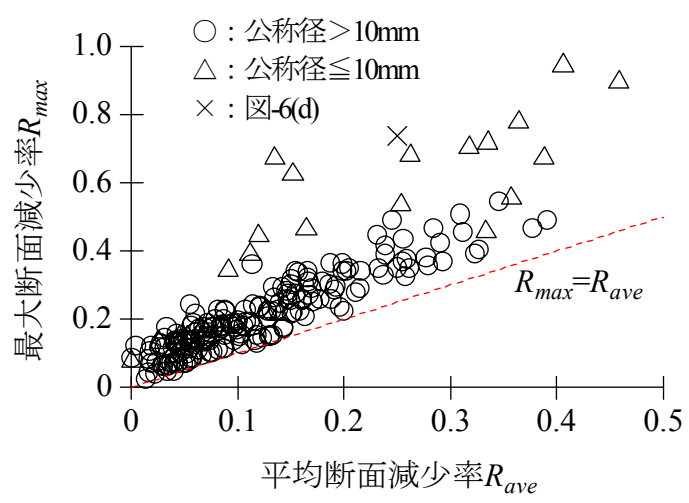

図-13 $R_{a x e}$ と $R_{\max }$ の関係 (測定結果)

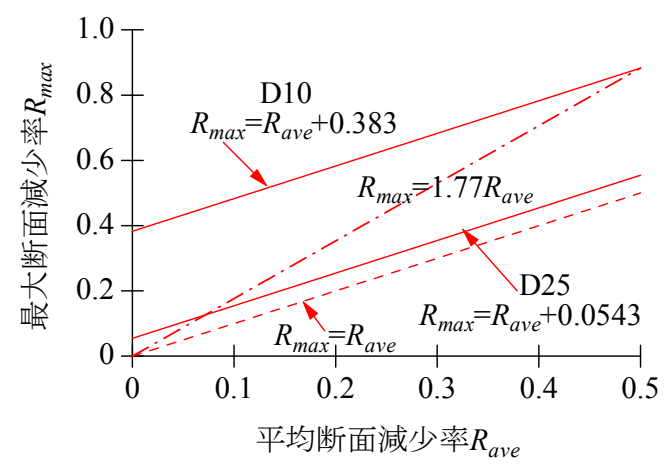

図-14 $R_{\text {ane }}$ と $R_{\max }$ の関係 


\section{(6) ノギスによる評価}

実構造物の調査において断面積の軸方向分布を取得す るには，本調查のようにレプリカによる方法が有効であ るが，現在行われている検査事例では，断面の任意の方 向からノギスにより測定した直径の最小值（ノギス最小 径）を用いることがある，そこで，本研究の調査データ から，ノギス最小径の調查により断面積の軸方向分布が どの程度の精度で把握しうるかを検討する.

本研究では，3D スキャンデータを用いてノギス最小 径を生成する，その方法を図-15 に示す，まず，3D ス キャンデータ $(x, y, z$ の点群データ)から, ある一定の高 さ $z$ の点群を抽出する. 実際の測定に準じて計算する場 合は，これらの点群に対して任意方向の最外縁距離 $s$ を 求め, 測定方向 $\theta$ を $0 \leqq \theta<180(\mathrm{deg})$ の範囲で変動させて $s$ の最小值を探査寸る必要がある（図-15(a)）。

本研究では計算を効率化するため, 以下の手順でノギ ス最小径を求める. 図-15(b)において, 点群の存在する $x$ および $y$ の範囲 $\left(s_{x}=x_{\text {max }}-x_{\text {min }}\right.$ および $\left.s_{y}=y_{\text {max }}-y_{\text {min }}\right)$ は, それぞれ $x$ 軸方向および $y$ 軸方向に測定した最外縁距 離になる. 最外縁距離を測定する方向を変動させて最小 值を探査寸るため, 原点（3D スキャナのターンテーブ ルの中心）に対する形状データの回転写像を求め, 同様 に $x$ 軸方向および $y$ 軸方向の最外縁距離を求める. こ れを $0 \leqq \theta<90(\mathrm{deg})$ の範囲で探査した最小值がノギス 最小径 $s$ となり（式(11)），これを用いると当該断面の 断面積は式(12)により算出される.
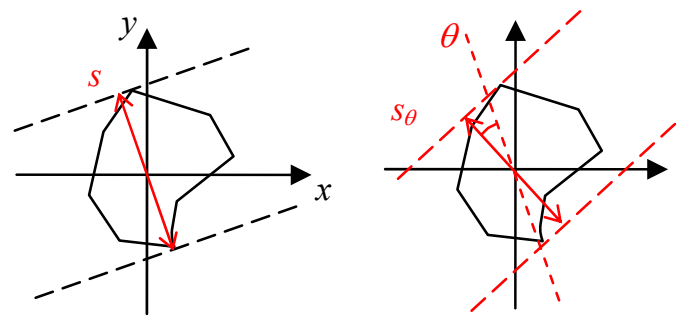

(a) 実際の測定に淮じた算出法（測定方向を回転）

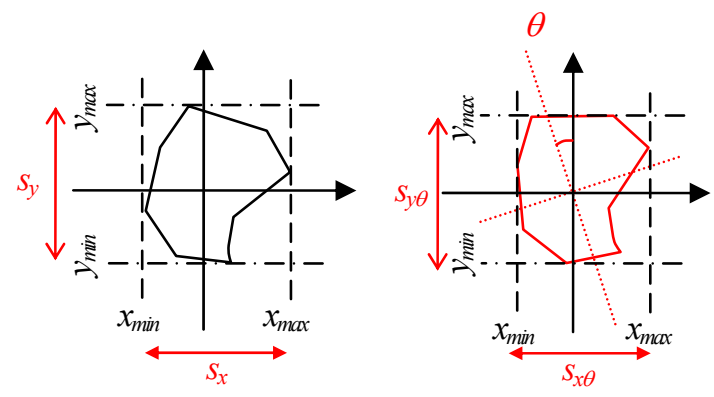

(b)本研究の算出法 (断面形状を回転)

図-15 スキャンデータからのノギス最小径の算出

$$
\begin{aligned}
& s=\min \left\{\min \left(s_{x \theta}\right), \min \left(s_{y \theta}\right)\right\} \\
& A_{C L P}=\pi(s / 2)^{2}
\end{aligned}
$$

算出した断面積の軸方向分布の例を図-16に示寸，調 查体 No.1 の鉄筋については, $A_{C P P}$ は比較的良好に断面 積 $A_{\text {local }}$ の軸方向分布を再現している. 一方, 調查体 No.3 の鉄筋については, 場所により $A_{C L P}$ は実際の断面 積 $A_{\text {boal }}$ より小さい值を示している. この鉄筋の断面は, 図-17に示寸ように片側から腐食し扁平な形状となって おり，このような場合はノギス最小径による断面積は実

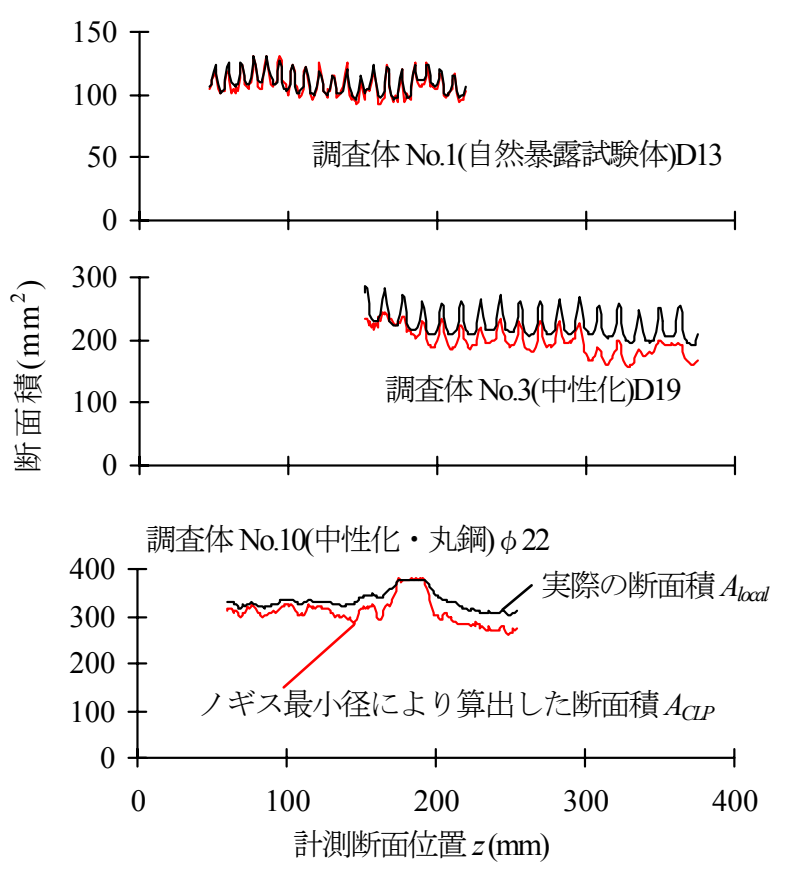

図-16 ノギス径により算出した断面積の分布

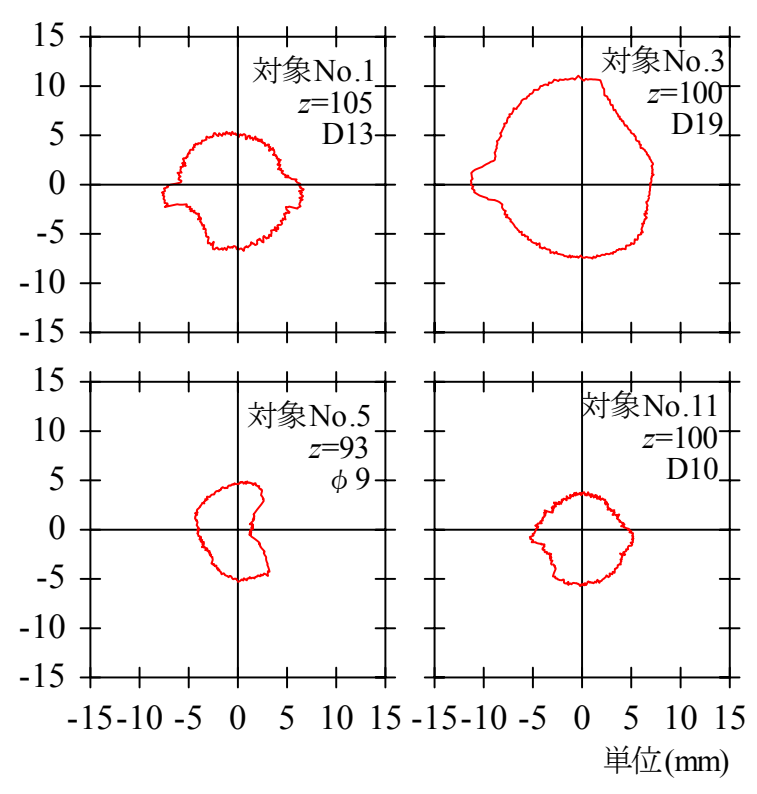

図-17 断面形状の例 
際の断面積よりも小さく算出されることになる. なお, このような場合でも，断面積を評価する場合は安全側 の変動となる．逆に，危険側への変動として，ノギス最 小径により算出した断面積がまれに当該箇所の断面積を 上回る場合がある，概念的には図-18 に付したような星 形の断面の場合に生じるが，図-16,17 に示したようにこ のような事例はあまりない.ノギス最小径により算出し た断面積 $A_{C L P}$ の試験片 1 本毎の平均值 $A_{a v e, C P}$ を, 各試験 片の平均断面積 $A_{\text {ane }}$ と比較して図-19 に示す. $A_{\text {ane } C L P}$ は $A_{\text {ave }}$ よりやや小さいが，ノギス最小径によって平均的に は概ね精度よく断面積を評価できることが分かる.

なお，本検討では3Dスキャナによる計測データを用 い，1mm間隔でノギス最小径を算出して断面積の考察を 行っているが，実際の調査では上述のほかに，測定技量 の差や測定状況（かぶりコンクリートのはつり深さ，ノ ギスの差込み易さおよび計測方向間隔等）によって が 変動すると予想される. 特に最小值の探査が不十分な場 合は，測定された值が実際より大きくなり危険側に見積 もることになるので，実務への適用に際しては実地試験 などによる作業性に対する検討が別途必要となる.

\section{5. 断面積分布を用いた鉄筋力学特性の評価}

\section{(1) 腐食鉄筋の引張試験}

これまで述べたように，腐食した鉄筋では断面積が 一様でないため，ある引張荷重が作用した時点のひずみ は断面により異なる，そこで，局部的な断面減少が鉄筋 の力学特性に与える影響を検討するため, 腐食鉄筋の試 験結果を用い，引張力下における任意断面のひずみの差 異について調べる.

引張試験では, 塩害で腐食した調査体No.11から採取 した鉄筋を用い，文献 に示した引張試験方法により， 腐食区間をはさむ設定間隔（公称径の16倍）にてターゲ ットを取り付け，区間全体の伸びを計測した。 また，断 面積の最も小さい断面（最も腐食した断面）および最も

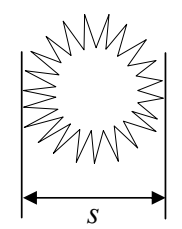

図-18 $A_{C L P}$ が $A_{\text {me }}$ を 上回る断面の イメージ

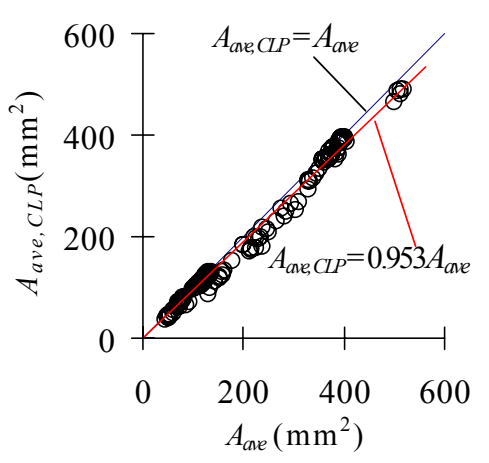

図-19 $A_{\text {are,CPP }} A_{\text {ane }}$ の比較
大きい断面（健全断面）の局部ひずみを，ゲージ長 $5 \mathrm{~mm}$ のひずみゲージにより計測した。

\section{(2) 引張試験結果}

腐食した鉄筋の荷重とひずみの関係を図-20に示す. なお, 縦軸は, 引張荷重を公称断面積で除した応力であ る. たとえば $\sigma=300\left(\mathrm{~N} / \mathrm{mm}^{2}\right)$ の引張荷重を与えている時 点では，腐食断面には $10000 \mu$ 程度のひずみが発生して 降伏しているのに対し，健全断面では $1500 \mu$ 程度のひず みしか生じていない. 図-20における区間平均の $\sigma-\varepsilon$ 関 係は，腐食断面と健全断面の中間に位置し，降伏点即ち 勾配が急変する点が明確でない. これより, 全体的な挙 動としては降伏が明らかでない場合でも，局部的には降 伏している場合があることが分かる.

\section{(3) 鉄筋力学特性の解析}

腐食鉄筋のひずみは断面積に依存すると仮定した単純 な力学モデル ${ }^{3)}$ により解析を行い, 引張試験結果と比較 して妥当性を検証する.

用いた力学モデル ${ }^{3)}$ は, 微小区間の両端に引張力が作 用した場合のひずみを，素材自体の $\sigma-\varepsilon$ 関係とその区 間の断面積からフックの法則により定まると仮定し, 評 価区間全体で積算して伸びを求めるものである. 1 力所 でも局所的に引張強度に達した段階で，解析を終了する。 このモデルでは，最小断面積は弾性限界と引張強度を支 配することになる.

解析と照合するための引張試験では, 中性化により腐

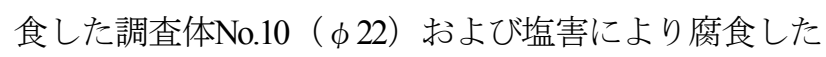
調査体No.11（D10）から採取した鉄筋を用いた．解析範 囲の断面積の軸方向分布を図-21に示す. 同図に示すよ うに，断面積の小さな突出部分（節先端や欠損部周縁部 分等）は剛性に寄与しない部分として控除し，解析に用 いた3).また，同じ調査体No.10およびNo.11から採取した 健全に近い鉄筋をそれぞれ1本ずつ引張試験に供し，ひ ずみを測定した個所の断面積から素材自体の $\sigma-\varepsilon$ 関係 を求めた。

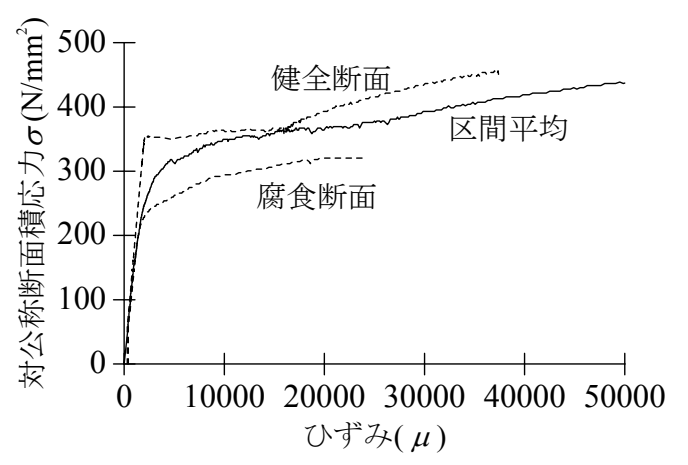

図-20 引張試験結果と各部のひずみ 
解析結果を実験結果と比較して図-22に示す。ここで は, 引張力を公称断面積で除して得た応力を縦軸とし, 評価区間の伸びを評価区間の長さで除して得たひずみを 横軸として表記した。 中性化による腐食を生じた調査体 No.10鉄筋 $(\phi 22)$ の解析結果は, $40000 \mu$ 以降のひずみ硬 化域を除き，実験結果と比較的良好に一致している。一 方，塩害による腐食を生じた調査体No.11鉄筋（D10）の 解析結果は, 降伏棚以降の応力一ひずみ関係はほぼ一致

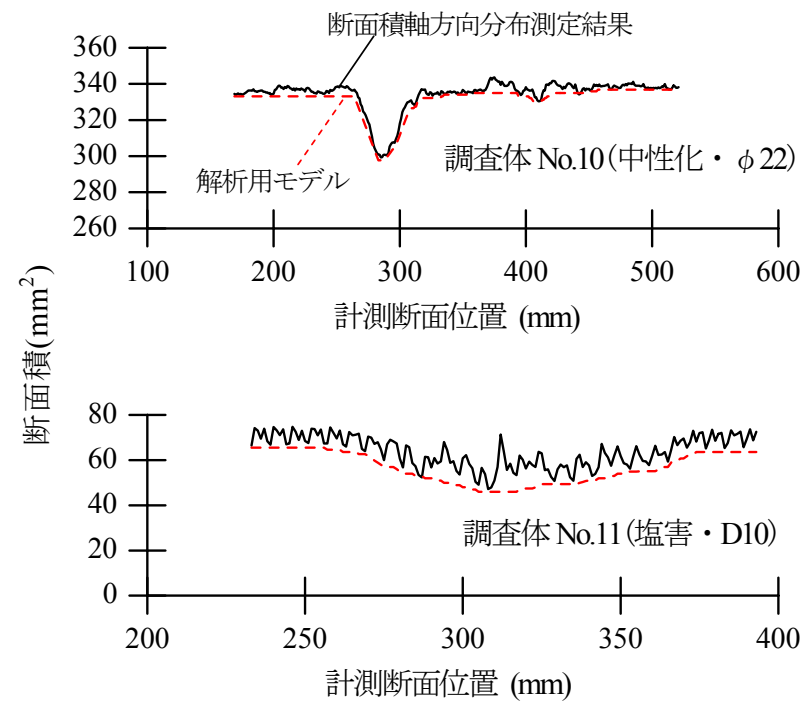

実線 : 断面積軸方向分布測定結果 破線 : 解析用モデル

図-21 引張試験片の断面積の軸方向分布

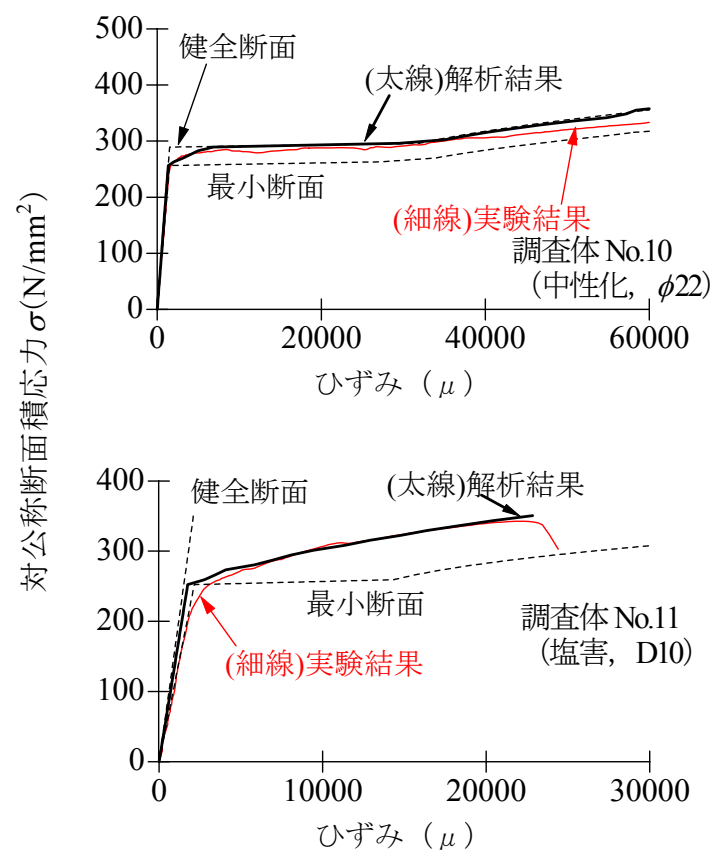

太線 : 解析結果 細線 : 実験結果 (破線の最小断面と健全断面は解析結果)
するものの，弾性限界が相違しており，実験結果（約 $200 \mathrm{~N} / \mathrm{mm}^{2}$ ) は解析結果 (約 $\left.250 \mathrm{~N} / \mathrm{mm}^{2}\right)$ の約 $80 \%$ である. 解析と実験でこのような差異を生じた原因として，同一 断面内でも降伏している部分と弾性域にある部分が混在 し，局部的に曲げを生じているにもかかわらず，解析で はこれをモデル化していない点が挙げられる.

このように，腐食した鉄筋では，調査体No.11のよう な細い鉄筋や欠損率の大きい鉄筋，形状が複雑な鉄筋を 除けば，ある程度は力学性状が解析可能と考えられる. また，弾性限界や引張強度などの情報は最小断面積によ り概ね確認できる. 先に述べたように, 最小断面積は平 均腐食量と標準偏差から推測でき，平均断面積はノギス 最小径やレプリカにより推測できるので，これらの知見 により，鉄筋の力学性状は現地での調査により把握でき るようになると考えられる，さらに，本研究で得た断面 積標準偏差や，腐食速度と経年から求まる平均腐食量を も活用するならば，鉄筋の力学性状の将来予測への展開 も可能となる.

\section{6. 結論}

本研究では，腐食した鉄筋の力学性状の検討のため, 腐食に伴う鉄筋断面積のばらつきの実態を調査し検討を 行った．実構造物における鉄筋の腐食のばらつきを把握 するための調査は広範囲かつ詳細であるほど望ましいが, 諸制約条件により十分な調査が行えないことが多い，そ こで本研究では，実際に採取した鉄筋に加え，鉄筋の採 取を要しない手法を新たに開発し併用して，現在の技術 レベルで可能な限り精緻（1mm ピッチで約 38000 断面） に腐食鉄筋の形状および断面積を測定し，考察を行った。 得られた知見を以下に要約する.

（1）実構造物の鉄筋腐食の調査手法の一つとして，レプ リカと $3 \mathrm{D}$ スキャナを用いた手法を開発した. この 手法を用いて実際に調査を行った結果，腐食の状態 の数值化に有効であることを確認した.

（2）実構造物を主体とする 11 の調査対象に対し，レプ リカと鉄筋の採取を実施し，断面積の変動を標準偏 差により検討した。この結果，平均断面減少量が大 きくなっても局所断面減少量の標準偏差はあまり変 化せず，最大断面減少量は平均断面減少量の関数で 表現できる可能性があることを確認した。

（3）本研究での調査方法および調査対象では，最大断面 減少量の期待值は平均断面減少量に一定量を加えた 值となり，またその值は断面減少量の標準偏差の平 均的な值 $8.8 \mathrm{~mm}^{2}$ の 3 倍となることを確認した。 ま た，本調査範囲では，塩害による腐食と中性化によ る腐食では最大断面減少量の平均断面減少量に対す 
る比に大差ないことが分かった．最大断面減少率に 対しては，元の鉄筋の断面積によって結果が大きく 変わるが，比較的細い鉄筋では最大断面減少率は平 均断面減少率のおよそ 1.8 倍となることが分かった.

（4）3D スキャンデータから $1 \mathrm{~mm}$ きざみでノギス最小径 を生成し，ノギス最小径による断面積の評価がどの 程度の精度で可能かを検討した。 その結果，片側か ら腐食し扁平な断面となった鉄筋で断面積を小さく 算出する場合があるが，平均的には概祇精度良く断 面積を評価できることを確認した。 なお，この結果 の実際の調査への適用については，作業性に対する 検討が別途必要であると考えられる。

（5）断面積の軸方向分布をモデル化した解析と引張試験 結果を比較した結果，腐食鉄筋の断面積の軸方向分 布を把握することで，細い鉄筋や欠損率の大きい鉄 筋を除き，実際の腐食鉄筋の力学性状が概妏把握で きることを確認した.

なお，本研究は国土交通省の補助金を受けて実施した。

\section{参考文献}

1) 日本コンクリート工学協会 : コンクリート構造物のリハビリ テーション研究委員会報告書, pp.43-74, 1998.

2) 松尾洋, 五角亘，下村匠 : 鉄筋が腐食した鉄筋コンクリート 部材の引張剛性, コンクリート工学年次論文集, Vol.23, No.3, pp.1327-1332, 2001.
3) 大屋戸理明, 金久保利之, 山本泰彦, 佐藤勉 : 鉄筋の腐食性 状が鉄筋コンクリート部材の曲げ性状に与える影響, 土木 学会論文集，部門 E, Vol.62，No.3，pp.542-554， 2006.

4) 柏原茂, 谷村幸裕, 泉並良二, 木村元哉 : 実構造物から採取 した腐食鉄筋の引張降伏強度推定に関する一考察, 土木学 会第 55 回年次学術講演会講演概要集, V-358, pp.718-719, 2000.

5) 大屋戸理明, 黒岩俊之, 早川健司, 岡本大 : 丸鋼を用いた $\mathrm{RC}$ 部材の長期供用後の曲げ而荷性状，コンクリート工学年 次論文集, Vol.25, No.2, pp.1921-1926，2003.

6) 大屋戸理明, 長谷川雅志, 佐藤勉 : 促進劣化させた鉄筋コン クリートはりの疲労性状, コンクリート工学年次論文集,

Vol.24, No.2, pp.961-966, 2002.

7) 大屋戸理明, 西脇敬一, 長谷川雅志, 永岡高 : 長期暴露した 鉄筋コンクリート梁の劣化性状と而力, コンクリート工学 年次論文集, Vol.23, No.3, pp.1315-1320, 2001.

8) 佐々木孝彦, 飯島亨, 立松英信, 大城武 : 塩分吸着剤を用い て補修した供試体の鉄筋腐食性状，コンクリート工学年次 論文集，Vol.23，No.1，pp.379-384，2001.

9) 加藤絵万, 岩波光保, 横田弘, 中村晃史, 伊藤始: 繰返し荷 重を受ける RC はりの構造性能に及ぼす鉄筋腐食の影響, 港 湾空港技術研究所資料，No.1079， 2004.

\title{
MECHANICAL CHARACTERISTICS OF CORRODED REINFORCING BAR BASED ON INVESTIGATION OF ACTUAL CONDITIONS
}

\author{
Michiaki OYADO, Toshiyuki KANAKUBO, Yasuhiko YAMAMOTO \\ and Toru IIJIMA
}

\begin{abstract}
Mechanical characteristics of corroded reinforcing bars in the reinforced concrete structures are not identical with those of bars without corrosion because the cross sectional area of corroded reinforcing bars are not uniformly distributed. In this study, both the distributions of the cross sectional area of corroded reinforcing bars in actual structural members and their effects on the mechanical characteristics of the bars are investigated. Firstly, an investigation method using the replica of corroded reinforcing bar is developed, and it is clarified that this method is effective to obtain the data of the shape of the corroded reinforcing bar. Secondly, the corroded reinforcing bars in actual railway reinforced concrete structures and their replicas are measured for their dimensions by the three dimensional shape scanner. It is confirmed that the maximum reduction of cross sectional area of a bar can be estimated by using the average reduction of cross sectional area and its standard deviations. Finally, the mechanical characteristics of the corroded reinforcing bars under tensile loading test are compared with the analytical results in which the reduction of cross sectional area in each section along the bars is taken into account.
\end{abstract}

